\title{
UK life science students seek better deal
}

[LONDON] Britain's life scientists are preparing to lobby the government to double the value of a doctoral student's stipend and add an optional foundation year to existing threeyear $\mathrm{PhD}$ programmes.

The moves follow concerns expressed by universities, research councils and industry that the quality of applicants for $\mathrm{PhD}$ courses in the life sciences is falling, and that urgent measures are needed to attract able students to research careers.

Life scientists also want to set up a body to lobby the government on their behalf. This stems partly from a belief that existing organizations have failed to communicate their concerns to government effectively.

The decisions came at the end of a daylong conference in London earlier this month on the training of life scientists. It was organized by the UK Life Sciences Committee, a year-old umbrella group made up of most of Britain's learned societies in the life sciences.

The conference covered most aspects of life-science research training. But a key issue was the urgent need to raise the level of a government-funded life science student's $\mathrm{PhD}$ stipend, bringing it in line with that offered by the Wellcome Trust.

Despite being topped up by $£ 1,000$ (US\$1,680) after the government's recent Comprehensive Spending Review, the $\mathfrak{E} 6,545$ annual PhD stipend is still considerably short of the average starting salary for graduate jobs in the United Kingdom.

Delegate after delegate rose to say that many bright students, already burdened with undergraduate debts, were unwilling to devote a further three - possibly four years earning "slave labour wages". A consensus emerged that the stipend needed to be doubled, even if this meant a cut in the numbers of PhD studentships.

John Lackie of the Yamanouchi Research Institute in Oxford said: "We produce far too many research students, and far too many of low calibre. A bigger stipend is needed. Industry needs excellence, not mediocrity."

This call was echoed by Malcolm Skingle of Glaxo Wellcome, who said his company had recently hired recruitment consultants to "scour Europe", as high-quality postdocs were becoming difficult to find in Britain.

Peter Swann, professor of biochemistry and molecular biology at University College London, said that he found himself offering $\mathrm{PhD}$ studentships to graduates whom he had earlier rejected. This was to fill vacancies created by better-qualified students who had decided to pull out.

Bob Price, director of Human and Corporate Resources at the Biotechnology and Biological Sciences Research Council (BBSRC), said that the BBSRC wanted to raise $\mathrm{PhD}$ stipends in the life sciences, but was ham-

strung by government policy that stipends remain equal across all research councils.

BBSRC's governing council would shortly be discussing the issue, said Price, adding that stipends should be set according to market demand. "The market for a life scientist is not the same as that for a physical scientist. If you are a space scientist, your options are not wide. But it is different in life science."

Delegates overwhelmingly endorsed the need for a foundation year as another way of attracting — and keeping — able students. There was considerable support for a fouryear $\mathrm{PhD}$ with a "get-out" clause in which students could leave after the first year with a master's degree. This would be similar to the existing research master's degree, MRes.

Some delegates were concerned that the extra year would leave British PhDs older, and thus potentially less marketable for nonacademic careers. But others pointed out that at 27 , a postdoc from Scotland who completed the extra foundation year was still much younger than a US or European counterpart.

The foundation year would be designed to train students in research skills, as well as expose them to a range of research projects under different supervisors so that their final

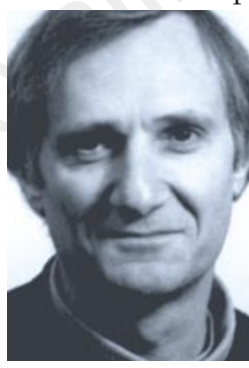

Martin Raff: original thinking is the key. more time should be given to transferable skills. Postgraduate departments offer such skills partly because of student demand, and because they recognize that many students will end up in industry, rather than academia.

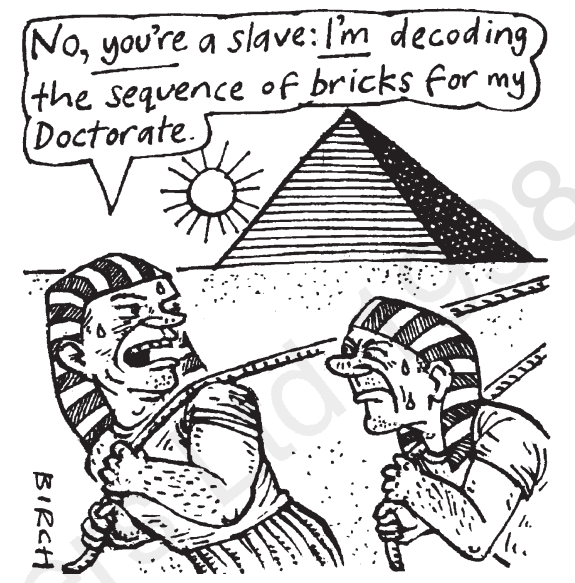

The overwhelming view of the conference was that the research content of a $\mathrm{PhD}$ should not be diluted. Most delegates acknowledged the value of transferable skills, but warned of the dangers of overemphasizing them.

"If we're not careful, we'll have lots of students with lots of communication skills, but with very little to communicate," said Mike Carter, professor of biological sciences at the University of Surrey.

By contrast, some delegates complained that British postgraduate education was too focused, and that many PhD students completed their three years without demonstrating evidence of what one delegate described as "the intellectual experience", or, indeed, of having read beyond their specialist subject.

"There's a lot of emphasis on training for industry," said Martin Raff, chairman of the UK Life Sciences Committee. "What is key is learning to think originally. Yet few students seem to show evidence of this."

One reason, in Raff's view, was the "antiintellectual" nature of some current life science research, particularly molecular biology. Raff said he sympathized with students who spent three years decoding the function of a single gene. However, he felt that the era of formula science would pass once the Human Genome Project was complete. EhsanMasood

\section{France to set up co-ordinating committee}

[PARIS] The French government has announced the creation of a national coordinating committee for research in the life sciences, to be attached to the ministry of national education, research and technology.

It will be chaired by Nicole Le Dourain, professor at the Collège de France in Paris, and will have twenty other members. These will include representatives of the nine public research organizations with interests in life sciences, among them Claude Griscelli, director-general of the biomedical agency INSERM, and Maxime Schwartz, director-general of the Institut Pasteur. Other members will be leading scientists such as the geneticist Jean-Louis Mandel.

The committee's task will be to propose and evaluate programmes coordinated among the research agencies, to advise the ministry on strategy, and to set up debates on research issues such as the organization of genome and 'post-genome' research, telemedicine and genetic engineering. The committee will be consultative, but, as well as replying to requests from the ministry, it will issue opinions on subjects of its choosing. 